\title{
GLOBAL COMPETENCE: A PREREQUISITE FOR A GLOBAL LABOR MARKET AND A CHALLENGE FOR EDUCATION
}

\author{
Aleksandra SYNOWIEC \\ Silesian University of Technology, Faculty of Organization and Management; aleksandra.synowiec@polsl.pl, \\ ORCID: 0000-0001-8251-2322
}

\begin{abstract}
The aim of the article is to recognize the essence of global competence for effective functioning on the global labor market. Global competence is understood as the ability to interact effectively in international and intercultural environments. The concept of global competence is based on mutual respect and an attitude of openness to cultural diversity. Presented study refers to the significance and necessity of global competence analyzed in literature concerning contemporary educational challenges.
\end{abstract}

Keywords: global education, education, globalization, labor market.

\section{Introduction}

The aim of the article is to discuss the concept of global competence and contribution of education in challenging the issues of sustainable development. A global competence as a multidimensional capacity responds to the requirements induced by socio-economic changes, such as the increasing role of migration, culturally diverse teams and intercultural encounters. The concept of global competence is examined in the context of the changing environment of the global labor market and the requirements that contemporary employees should perform. The study has a theoretical character and is based on literature analysis.

\section{Globalization and education}

The question of education and development is still the most important in terms of fundamental changes people face in the stage of "liquid modernity" (Bauman, 2010, p. 1). The more globalized and fragmented the world is - the greater is the role of education in challenging the issues of social cohesion, inclusion and democratic participation. Globalization, 
according to Giddens (1990), is "the intensification of worldwide social relations which link distant localities in such way that local happenings are shaped by events occurring many miles away, and vice versa" (p. 64). This in consequence, influences societies, organizations and individuals. Jacques Delors (1996), the author of the assessment Learning: The Treasure Within, the Report to UNESCO of the International Commission on Education for the Twentyfirst Century, emphasizes the essential task of contemporary educational policies, which "can help to create a better world, by contributing to sustainable human development, mutual understanding among peoples and a renewal of practical democracy" (p. 14). The principle to leave no one behind vividly applies to education as a tool for increasing cultural and diversity awareness and overcoming inequalities.

On the other hand, the global landscape is being transforming continuously; Veronica Boix Mansilla and Anthony Jackson (2013) define three factors that have significantly changed the socio-economic conditions we live in: the flattened global economy and changing demands of work; migration and immigration creating more culturally and linguistically diverse societies, and climate instability and the growing need for global environmental stewardship" (p. 2). In order to meet new expectations resulting from the process of transition, new sorts of capacities are necessary. The new requirement for thriving in contemporary culture is called global competence (Reimers, 2009; Boix Mansilla, and Jackson, 2013; Verger, 2014; Verger, and Curran, 2014; Murray, 2014).

The issue of global competence is not limited to the education discourse. The authors of the $6^{\text {th }}$ World Bank's Report Skills, not Just Diplomas explain the context for necessity of developing new skills: "New skills have come into demand, as employment has been allocated away from declining industries and firms, towards expanding ones. In addition, there has been a large-scale shift of jobs from agriculture and, to a lesser extent, industry towards the service sector" (Sondergaard, Murthi, et al., 2012, p. 17). In turn, Cascio and Boudreau emphasize that the evolution of global business requires "the search for global competence - managerial, cultural, and operational. Global competence is embedded in organizational talent and the systems and leadership that organize and deploy it, but it is increasingly embedded within a workforce that lies beyond the familiar boundaries of regular full-time employment, and is empowered by technologies, platforms and connectedness (...)" (Cascio, and Boudreau, 2016, p. 103). The challenges of the modern labor market faced by employers and employees entail the development of competencies essential in today's ever-changing global environment. Kuzior and Sobotka (2019) noted that "along with the development of the economic reality described as Industry 4.0, questions about the role and function of Society 4.0 appear more and more often in the public debate" (p. 64). This discussion is evidently followed by considerations on present, as well as future labor competencies. Such circumstances determine the need for continuous education for employees and at the same time demand the appropriate education institutions response to prepare graduates for modern labor market requirements. 


\section{Global competence for global workers}

Brookings has recently stated that according to experts' predictions, "by 2030, 825 million children in low- and middle-income countries - half of today's youths' generation - will reach adulthood without the skills they need to thrive in work and life" (Brookings.edu, 21.05.2018, para. 1). An important aspect within the framework of the question of education of the future is also to recognize the essence of shaping global competence for effective functioning in the global labor market. "Twenty-first century students live in an interconnected, diverse and rapidly changing world with the increasing role of intercultural encounters" (PISA, 2018, p. 4). Education meeting modern needs is a new challenge. Taking it into consideration, in 2015 17, Sustainable Development Goals (SDGs) were adopted by the General Assembly of the United Nations to be achieved until 2030; goal number four was education (PISA for Development Brief 2017/09, para. 1). Inclusive and quality education "enables upward socioeconomic mobility and is a key to escaping poverty. Education is also essential to achieving many other Sustainable Development Goals" (UN Sustainable Development Goals: 4 Quality Education, 2015, para. 2).

There is no doubt that comprehensive implementation of sustainable development objectives depends on systematic education and continuous broadening of the sphere of social awareness (Kuzior, 2006, p. 71). Education, as Jacques Delors (1996) acknowledges, is the key for both personal and community development; "its mission is to enable each of us, without exception, to develop our talents to the full and to realize our creative potential, including responsibility for our own lives and achievement of our personal aims" (p. 17).

One of the targets defined for Quality Education is described as "promotion of a culture of peace and non-violence, global citizenship and appreciation of cultural diversity and of culture's contribution to sustainable development" (UN Sustainable Development Goals: 4 Quality Education, 2015, para. 10). Whether this can be achieved depends to a large extent on teaching philosophy and curriculum in schools or higher education institutions. It is thus inevitable to foster contemporary concepts in education, such as education for sustainable development, global education, global competence global citizenship, peace education and $21^{\text {st }}$ century skills and to adopt them into education agenda and policies (Verger, 2014; Verger, and Curran, 2014; Murray, 2014).

Global education as an umbrella concept is understood as extending "the scope of civic education and upbringing to a global perspective, by making people aware of the phenomena and interdependencies that connect people and places. Its aim is to prepare recipients to face the challenges of all humanity. By interdependence, we understand the interconnectedness and diffusion of cultural, environmental, economic, social, political and technological systems. Global education puts a special emphasis on: explanation of the causes and consequences of the phenomena described; showing the individual's influence on global processes and the 
impact of global processes on the individual; overcoming existing stereotypes and prejudices; presenting the global perspective of the South; shaping critical thinking and changing attitudes" (Lipska-Badoti et al, 2011, p. 4). Therefore, global education means an educational approach focused on developing understanding of other cultures and cultural interconnection. The idea of global competence derives from other concepts of global education mentioned above and is oriented on fostering understanding of the contemporary world and increasing the participation in society.

PISA - the OECD Program for International Student Assessment - explains that global competence is a multidimensional capacity that enables individuals "to examine local, global and intercultural issues, understand and appreciates different perspectives and world views, interact successfully and respectfully with others and take responsible action toward sustainability and collective well-being" (PISA, 2018, p. 4). According to Fernando M. Reimers, Director of the Global Education Innovation Initiative and the International Education Policy Master's Program at Harvard University, global competence is: "The knowledge and skills people need to understand today's flat world and to integrate across disciplines so that they can comprehend global events and create possibilities to address them. Global competencies are also the attitudinal and ethical dispositions that make it possible to interact peacefully, respectfully, and productively with fellow human beings from diverse geographies" (2009, p. 184). Polish pedagogist Urszula Dernowska (2013) underlines that global competence is "the ability to effectively interact with other people - people who speak different languages, who profess different religions, who believe in different values" (p. 22).

In other words, global competence incorporates attributes in the sphere of knowledge, skills and values, and enables one to act in international and intercultural environments, and to interact on the ground of mutual respect and openness to cultural diversity. Hence, as Veronica Boix Mansilla and Anthony Jackson (2013) claim, the globally competent student should acquire four competences indispensable to perform in globalized world: "Investigating the world beyond their immediate environment; framing significant problems and conducting wellcrafted and age-appropriate research; recognizing the perspectives of others and their own; articulating and explaining such perspectives thoughtfully and respectfully; communicating ideas effectively with diverse audiences, bridging geographic, linguistic, ideological, and cultural barriers; taking action to improve conditions, viewing themselves as players in the world and participating reflectively" (p. 2).

Global competence as an educational concept is reflected in the forecasts of competences inevitable for modern organizations. The Institute of the Future (Davies, Fidler, and Gorbis, 2011) defines ten skills for future workforce: 1) Sense-making, 2) Social intelligence, 3) Adaptive thinking, 4) Cross-cultural competency; 5) Computational thinking and data-based reasoning, 6) New-media literacy and persuasiveness, 7) Trans-discipline understanding and integration, 8) Design mindset in external environments, 9) Cognitive load management, 10) Virtual collaboration. The need for global competence is a response for conditions 
encountered in multinational and multicultural societies, and accompanies sociological, philosophical and legal reflection on multicultural reality in the era of globalization.

One of the most challenging issues for modern societies is multiculturalism, as the questions of ethnic, linguistic, religious or cultural diversity, the phenomenon of the coexistence of groups with different cultural backgrounds within a given territory and institutional solutions regulating their status and mutual relations are the subject of sociological, political, philosophical and legal reflection. Researchers undertake analysis of the phenomenon of multiculturalism both from an ethnic perspective - where ethnic bond is the foundation of identity, cultural content is passed from generation to generation, and cultural diversity is a consequence of migration, conflicts, wars, border changes - and from a non-ethnic perspective, which applies to social categories that differ in the field of normative systems, articulated interests or cultural practices (Mucha, 2005, p. 57). In the first approach, the subject of reflection will be multinational and multi-ethnic societies, immigrant societies; in the second, however, the processes of emancipation of social and cultural minorities are considered.

The idea of multiculturalism as an important and meaningful interdisciplinary category describing the dilemmas of the modern world is very capacious - hence, a multitude of interpretations and definitions of this concept can be found in literature. Marian Golka (2010) defines multiculturalism "as one of the incarnations of pluralism, a broader category covering all the plurality and diversity of social groups, layers and categories as well as their political, economic, social and cultural features functioning in society" (p. 65.). Therefore, according to the analysis of The Institute of the Future (Davies, Fidler, and Gorbis, 2011), "cross-cultural competency will become an important skill for all workers, not just those who have to operate in diverse geographical environments.

Organizations increasingly see diversity as a driver of innovation. Research now tells us that what makes a group truly intelligent and innovative is the combination of different ages, skills, disciplines, and working and thinking styles that members bring to the table" (p. 9). The role of education should not be forgotten while dealing with the new requirements concerning social networks, or discussion over global issues.

\section{Global competence: employers' perception}

One of the most important challenges for contemporary organizations, as Józef Ober underlines (2016) is "finding, hiring and keep the right employees with the right skills, experience and knowledge that are in line with what the company expects" (p. 353). Skills are usually divided into hard (job-specific, technical, technological) and soft (connected with emotional intelligence). The Cambridge Business English Dictionary defines soft skills as people's abilities to communicate with each other and work well together. The turn towards 
soft skills has been already noticed both by researchers and practitioners - soft skills seem to have become the new hard skills". Recent research shows that " $94 \%$ of recruiting professionals believe an employee with stronger soft skills has a better chance to being promoted to a leadership position than an employee with more years of experience but weaker soft skills (Forbes, 18.08.2017, para. 1). Communication, teamwork, adaptability, empathy, work ethic, problem solving and collaboration - these are attributes inevitable to become successful in work life. Strong communication skills and willingness to learn new things are valued by employers (Edsurge.com, 12.06.2019, para. 1-5). What is significant - the list of $21^{\text {st }}$ century skills is composed mainly of soft skills: 1) critical thinking; 2) creativity; 3) collaboration; 4) communication; 5) information literacy; 6) media literacy; 7) technology literacy; 8) flexibility; 9) leadership; 10) initiative; 11) productivity; 12) social skills (Applied Educational Systems, access date 27.07.2019). What is, therefore, the difference between soft skills and global competence? Competence - as OECD Program for International Students Assessment explains (2018), is much more than skill, since it is "a combination of knowledge, skills, attitudes and values successfully applied to face-to-face, virtual or mediated encounters with people perceived to be from a different cultural background (PISA, 2018, p. 7). The quoted document also emphasizes that acquiring global competence is a life-long process.

According to PISA, global competence consists of four dimensions that shape globally competent people who: 1) examine issues of local, global and cultural significance; 2) understand and appreciate the perspective of others; 3) engage in open, appropriate and effective interactions across cultures; 4) Take action for collective well-being and sustainable development (PISA, 2018, pp. 7-11). The first dimension of global competence refers to purposeful using knowledge and critical thinking when it comes to making judgments on global and intercultural issues. It requires skills such as selecting and weighing arguments, thus media literacy and effective use of media. The second dimension indicates willingness and capacity to understand global issues from different perspectives, regarding that they result from a system of reference that construct, objectified social reality (Berger, and Luckmann, 1991). This means that globally competent individuals consider that values and behavior of others are influenced by different concepts of reality.

The third component of global competence stresses the ability to interact appropriately with people from different background; i.e. not only understanding the others, but also having the capacity to be responsive and prepared for a dialogue. "Diversity will, therefore, become a core competency for organizations over the next decade. Successful employees within these diverse teams need to be able to identify and communicate points of connection (shared goals, priorities, values) that transcend their differences and enable them to build relationships and to work together effectively" (Davies, Fidler, and Gorbis, 2011, p. 9). 
Last, but not least, a further trait, being active and self-conscious members of society, is fundamental to survival in the Fourth Age. Such individuals are those able to mobilize resources in order to respond to local, global and intercultural issues. These attributes are described and implemented through four equivalent measures (PISA, 2018, pp. 12-18):

1) knowledge - knowledge about global issues, intercultural knowledge, knowledge about environmental issues, socio-economic development and interdependence;

2) skills - cognitive, communication and socio-emotional complex patterns of thinking or behavior inevitable to achieve a goal;

3) attitudes - mind-set of beliefs or feelings toward a person, a group, an institution, an issue, a behavior, a symbol;

4) values - standards used consciously and unconsciously as a reference for judgments.

It is difficult to question the necessity of establishing global competence around the world, considering the global issues and globalization processes we all are subjected to, no matter where we live. The authors of The Global Skills Gap Report in the $21^{\text {st }}$ Century (2018) confirm the commonly known fact, "that universities do not necessarily provide enough opportunities for students to develop skills critical for the labor market" (p. 5) and lay bare that the most important skills across the globe are considered to be problem-solving, the ability to work in a team, and being communicative (p. 8). In the case of business education, Kedia B.L. and Englis P.D. (2011) identifies "a disconnect between global economic realities and the ability of business schools to produce global managers. The gap between traditional business education programs and the business skills set that students need to deal effectively with the global marketplace was noted over two decades ago" (p. 325-326). Still, many of these skills can be developed through existing subjects or special courses taking advantage of processes of internationalization of institutions of higher education, as well as internationalization at home policies.

\section{Conclusion}

The concept of global competence is inevitable while challenging the issues of sustainable development, global organizations and global workers. There is a need for establishing global competence as a multidimensional capacity recognizing the socio-economic requirements of today's labor reality, including the increasing role of migration and intercultural issues, culturally diverse teams and intercultural encounters. The notion of global competence is connected with the changing environment of the global labor market and of requirements that contemporary employees should perform. This concept is strongly present in contemporary literature, and is particularly evident in studies on the role of education in the globalized world. 
Moreover, it is noticeable in countries that have recently undergone socio-economic transformation and have become an attractive destination for labor migration - such as Poland.

\section{References}

1. Applied Education Systems, available online: https://www.aeseducation.com/careerreadiness/what-are-21st-century-skills, 27.07.2019.

2. Bauman, Z. (2010). 44 letters from the Liquid Modern World. Cambridge: Polity Press.

3. Berger, P.L., and Luckmann, T. (1991). The Social Construction of Reality. A Treatise in the Sociology of Knowledge. Penguin Books.

4. Boix Mansilla, V., and Jackson, A. (2013). Educating for Global Competence: Learning Redefined for an Interconnected World In Heidi Jacobs. Mastering Global Literacy, Contemporary Perspectives. New York: Solution Tree.

5. Brookings.edu, Citizens of the future: Innovations to leapfrog global education. Accessible online: https://www.brookings.edu/events/citizens-of-the-future/, 27.07.2019.

6. Cascio, W.F. and Boudreau, J.W. (2016). The search for global competence: From international HR to talent management. Journal of World Business, 51, 103-114.

7. Davies, A., Fidler, D., Gorbis, M. (2011). Future Work Skills 2020. Palo Alto, CA: Institute for the Future. Accessible online: http://www.iftf.org/uploads/media/SR-1382A_UPRI future_work_skills_sm.pdf, 28.07.2019.

8. Delors, J. (1996). Learning: The Treasure Within, the Report to UNESCO of the International Commission on Education for the Twenty-first Century. UNESCO Publishing. Retrieved from UNESDOC Digital Library: https://unesdoc.unesco.org/ark:/48223/ pf0000109590, 26.07.2019.

9. Dernowska, U. (2013). Kompetencja globalna w szkole. Przeglad Pedagogiczny, 2, 17-32.

10. Giddens, A. (1990). The Consequences of Modernity. Stanford: Stanford University Press.

11. Golka, M. (2010). Imiona wielokulturowości. Warszawa: Warszawskie Wydawnictwo Literackie „Muza SA”.

12. Kedia, B.L. and Englis, P.D. (2011). Transforming business education to produce global managers. Business Horizons, 54, 325-331.

13. Kuzior, A. (2006). Człowiek jako racjonalny podmiot działań w świetle założeń koncepcji zrównoważonego rozwoju. Problemy Ekorozwoju, 1, 2, 67-72.

14. Kuzior, A. and Sobotka B. (2019). Key competencies in the modern business services sector. Organization and Management Scientific Quarterly, 2(46), 63-74, doi: 10.29119/ 1899-6116.2019.46.5. 
15. Lipska-Badoti, G., Rostek, B., Szczygieł, P., and Witkowski, J. (2011). Edukacja globalna w szkole. Każdy nawija. M. Metera, K. Wojda (eds.), Warszawa: Centrum Edukacji Obywatelskiej, Polska Akcja Humanitarna.

16. Mucha, J. (2005). Oblicza etniczności. Studia teoretyczne i empiryczne. Kraków: Zakład Wydawniczy Nomos.

17. Ober, J. (2016). Employer branding - strategia sukcesu organizacji w nowoczesnej gospodarce. Zeszyty Naukowe Politechniki Ślaskiej Seria: Organizacja i Zarządzanie, 95, 345-356.

18. OECD, PISA 2018 Global competence. Accessible online: http://www.oecd.org/pisa/pisa2018-global-competence.htm, 27.07.2019.

19. OECD, PISA for Development Brief 2017/09. Accessible online: https://www.oecd.org/ pisa/pisa-for-development/17-PISA-D-and-SDG4.pdf, 27.07.2019.

20. QS Intelligence UNIT, The Global Skills Gap Report in the $21^{\text {st }}$ Century, Retrieved from: https://www.qs.com/the-global-graduate-skills-gaps/, 15.07.2019.

21. Reimers, F.M. (2009). Educating for Global Competency. In J. Cohen, M. Malin (Eds.), International Perspectives on the Goals of Universal Basic and Secondary School (pp. 183202). Routledge Press.

22. Sondergaard, L., Murthi, M. et al. (2012). Skills, Not Just Diplomas. Managing Education 9 for Results in Eastern Europe and Central Asia. Washington: The World Bank.

23. Tate, E. (2019). Edsurge.com. Students in Tech Say Soft Skills and Arts Set Them Up for Success. Accessible online: https://www.edsurge.com/news/2019-06-12-students-in-techsay-soft-skills-and-the-arts-set-them-up-for-success, 27.07.2019.

24. United Nations Sustainable Development Goals, Education. Accessible online: https://www.un.org/sustainabledevelopment/education/, 27.07.2019.

25. United Nations Sustainable Development Goals, Quality Education - why it matters? Retrieved from: https:/www.un.org/sustainabledevelopment/wp-content/uploads/2017/ 02/4.pdf, 27.07.2019.

26. Verger, A. (2014). Why do policy-makers adopt global education policies? Toward a research framework on the varying role of ideas in education reform. Current Issues in Comparative Education, 16, 2, 14-29.

27. Verger, A., and Curran, M. (2014). New Public Management as Global Education Policy: Its Adoption and ReContextualisation in a Southern European Setting. Critical Studies in Education, doi: 10.1080/17508487.2014.913531. 